\title{
Driving Factors and Their Characteristics of Prostitutes in Indonesia: A Phenomenology Approach
}

\author{
Sri Hartini Jatmikowati \\ Faculty of Social and Political Sciences, University of Merdeka, Malang, Indonesia
}

Doi:10.5901/mjss.2015.v6n6s1p554

\begin{abstract}
The research discusses about the factors driving a women turn themselves to become prostitute in prostitution business in Indonesia. The study was conducted in the village Slorok, Malang, Indonesia, where there is an old localization. The study uses descriptive and analytical approaches that highlight the importance of examining and analyzing the life of a phenomenon of the commercial sex workers. Several factors that make women become prostitutes are identified, including household violence, poor economics condition, debts, low income, skills, and low education.
\end{abstract}

Keywords: prostitution, phenomenology, localization, women, sex workers

\section{Introduction}

Prostitution is from Latin, prostituere or pro-stauree, which means allowing oneself to commit adultery, fornication, and sexual abuse (Purnomo and Siregar, 1985). Although, so far most of the prostitutes who are seen in public are women, but actually prostitutes could be men or women. But, it appears as common understanding that prostitutes are always women and so-called women prostitutes (WTS). Since the product of a prostitution business is sexual intercourse, then prostitutes can be defined as a woman or man who has habit of having sex outside of marriage, either paid for the service or not. In prostitution world, sexual intercourse is only considered as entertainment and business, so that there is no respect for legitimated marriage.

Prostitutes is immoral profession which is categorized as less civilized because prodigality of sexual relations in the form of surrender of women to men for sexual gratification to gain compensation or money for the service. Prostitutes can also be interpreted as a wrong behavior or fail to conform to existing norms of decency in a society. A woman prostitute is a woman who has inappropriate behavior and can bring harm and disease for her and others who associate with. In Indonesia, the sex workers have another name, namely commercial sex workers (PSK). The term is often referred to as WTS, slut, female sex workers, or strumpet. In Java community, they are often called the balon or sundel. All those designations for women who work as prostitute are certainly harsh for women.

Another very alarming fact about prostitution is that the number of sex workers are relatively constant due to natural regeneration from time to time. Young sex workers present in a localization with all problems of life try to look very elegant and make a lot of money. They got rid of his predecessor who are getting old. As they get older, there are another generations of young sex workers who replaced them. This regeneration occurs naturally, either due to available information or deliberate of women to plunge themselves into the prostitution world as a result of broken heart or the burden of social and economic life to bear in society. Morally, prostitution is regarded as a disease of society whose actors are considered bereft of decency or less civilized. Sex workers are considered as prostitutes because they have behavior which are distant or even opposed to the moral norms prevailing in a society. The prostitute are very susceptible to trouble and dangerous diseases in the community, either for himself or others. Due to to background, the objective to the research is to reveal, to describe and to analyze the motivation of the involvement of commercial sex workers in brothels of Village Slorok Kromengan District of Malang.

\section{Literature Reviews}

\subsection{Commercial Sex Workers}

Sexual problems are things that have been happened by the wider community. In Indonesia, the problem of sex is still considered taboo in public spaces. As a result, although present in society, sex is not fully known and understood. Sexual 
problems are often isolated in the age limit so that it is as if authority of adults, not children or adolescents. Therefore, children or teenagers who have started to recognize sex and experience an increasing curious feeling tend to look for information about sex. In fact, they usually make great efforts through masturbation, petting or intercourse with a woman without a marriage bond. The impact is the strengthening tendency to free sex. They will vent the gratification of sexual desire which tends not in place or violate social norms.

Prostitution has been a big business some groups of people. Edlund and Korn (2002) explained the wage compensation received by prostitutes. They mentioned that the prostitution is like usual market that everyone tries in the business cycle tries to do business. People who provide sexual services in their profession are called prostitutes. When it is said as a profession, this profession probably is the most hated by the Indonesian people, in general, but most preferred by an individual or a social group who need it. That is one reason why prostitution is always present.

Although there is always the eviction program, but localizes or isolation is done by the community and order officers, but the prostitution remains and survives longer in the community. This would seem to be a sign that the presence of the prostitution is not solely because of women providing sexual services, but there are many individuals or certain social group who are morally not feel awkward enjoying the sexual services. As long as there is demand, the market law says that the deals will always present itself. In this case, slut is the provider who is good at seeing business opportunities in sexual service outside legitimated marriage for entertainment and pleasure.

There are significant numbers of articles discussed about types of prostitution. According Kartono (2009), there are several categories of perpetrators of prostitution, namely mistresses, cougar, call girls, bar girls, young naughty girl, rebellious girl, etc. Santo and Etheredge (2004) described some characteristics of prostitution in brothels and prostitutes in Dakar, Senegal. They found that young African women are vulnerable to HIV infection because sexual relations with men are an important means to achieve social and economic status, and for some women they are necessary for survival. Meanwhile, Chang and Weng (2012) used a unique random survey of prostitutes in Taipei city of Taiwan. This study investigated the association between obesity, condom use and prostitutes' price. Jackson et al (1992) outlined three different types of prostitutes which are street prostitutes, escorts, and prostitutes who work part time in the service sectors. Based on the status of prostitution and the rates charged, Soedjono (1977) mentioned that there are three categories of prostitutes:

\subsubsection{Low Class}

Prostitutes of this class are usually hanging along public places and can be termed as street prostitutes. They are normally living in brothels or suburban homes with very low rates. Their customers are the factory workers, small traders, rickshaw drivers, and others who earn small amount of income. Sometimes, there are also young people with a lot of money who just want to release the sexual urge with prostitutes as well as for fun. Sometimes in this type of prostitute, there exist a woman from a good neighborhood and background but later lost due to various reasons such as job seekers trapped by brokers. There is also worse condition when there is a woman who is deliberately exploited by her own mother who is also acting as an intermediary. This class prostitutes are most harmful to society, because most of them were seized with venereal disease and disrupting life and health of young man.

\subsubsection{Middle Class}

Prostitutes of this class usually stay at fairly clean-environment guess houses or brothels. They good look, flawless, well dressed and have more courteous behavior. The service charge for them is higher than the low class prostitutes. Those who become customers usually people with fairly enough money. Prostitutes in cities who are looking for customers from among the sailors or foreigners can be categorized into this category. In terms of danger from venereal diseases such as HIV, prostitutes of this class are relatively more secure because basically they concern about their own health and appearance as well as much more aware to check their health condition to doctor.

\subsubsection{High Class}

Prostitutes of this class often stay in relatively good hotels, high class restaurants, or in their own house. Their look, cloths, and physical condition are more perfect than the middle class and their tariffs are also higher. They usually provide themselves to be contacted to order. They regularly check their health to the medical center. Women in this category usually become prostitutes for having some experience. Sometimes they are married women, with the intention of improving their social status. 
In the world of prostitution, many parties are involved and not only the prostitutes themselves. There are several other parties who are involved in this business. The presence of these people are, in fact, as reflection of business response, which mean that they are responsive to the nature of the sexual human instinct which has potential to deviate from the common norm of marriage in the form of prostitution. According to (Soedjono, 1977), those who are involved in prostitution business are:

a. Prostitutes,

b. Prostitutes' customers: people who pay prostitutes to satisfy the sexual instinct in achieving sexual satisfaction,

c. Pimps: people whose livelihood hold or participate in holding, finance, lease, open and lead and organize places for the practice of prostitution, namely by arranging meeting between prostitutes and customers. Typically, the pimps take most of the income obtained by the prostitutes,

d. Pander: people whose livelihood is to bring prostitutes to customers or vice versa,

e. Woman traders or sellers: women who are looking for profits to persuade girls/women to come to the prostitution business. They provide women for prostitution in certain areas, from rural to urban areas or other rural to suburban localization in other areas, and,

f. lover or "mistress" of a prostitute or pimp, who is a man who became a prostitute with a heart outpouring role as a lover or boyfriend who sometimes also become intermediaries and protectors for the prostitutes. Among the tasks pimps are to protect prostitutes against the police, take care of their job, and protecting against fussy clients. However, not all prostitutes have a lover. Instead, some of them are doing their own without pimps and brokers.

In practice, all those the actors live by the earnings from prostitutes, or even become criminals in the life of a prostitute. In this context, prostitutes are the main victims of prostitution business professions.

\subsection{Environmental Conditions}

The question which often arises in society towards commercial sex workers is whether commercial sex workers are enjoying their profession so that they are able to last long in the business which is known very susceptible to harm, violence, and having high risk of dangerous disease? For commercial sex workers, staying in brothels is not for pleasure, but for survival. Although their exterior live looks glamorous, always preening and highlight eroticism, not a few of them suffer in such profession. Sometimes they feel regret in their hearts and want to get out of prostitution for become human with a better livel, but because of economic difficulties, the intention is often frustrated and short-lived in the flashes of hope.

According Kartono (2009), there are striking characteristics symptom occurs in commercial sex workers, which quickly grow old and wither. This is due to several causes, such as:

a. they have bad habits, such as eating, late sleep, and work at night irregularly and less rest,

b. too much working load,

c. they do relationship with many abusive men, so that the body is often exploited,

d. they often get dangerous infections, miscarried which result in menstrual disorders so that it can accelerate the body damage or withering body,

e. too much consume drugs to maintain body health and too much drinking liquor which has high alcohol content).

Most of the commercial sex workers usually aware that prostitution is a job which cannot be done in a long run, so that they had already begun saving money from the beginning of their profession. According Kartono (2009), at the age of 30 years, many conflicts arise in the commercial sex workers themselves. They think that if the job as commercial sex worker is continued, then the body will definitely not strong anymore, and their beauty will be started to fade so that their income be greatly reduced. On the other hand if they quit their job, they imagine a serious inner poverty which often can transform them into a mental disorder. When they gets older, many inner conflicts will appear in commercial sex worker, because they will lost many customers and gets poor given their physical condition is much reduced from time to time.

For commercial sex workers who still have enough intelligence to switch professions, just before they get withered by age, they switch to a lighter type of work, such as become a pimp, massage shaman, abortion shaman, seller of herbal medicine, and others. Meanwhile, commercial sex workers who are not able to make adjustments would normally fall further slip in the lower-level prostitution, criminal act and even until go to jail because of crime or abandoned and lonely in hospitals or nursing homes. 


\subsection{Phenomenology of Commercial Sex Workers}

Since ancient times, prostitutes have been always criticized or condemned by the public, because their behavior is immoral and considered littering sacred sex. They have been referred to as those who violate moral norms, customs and religions, even sometimes also violate the norms of a state, if the state forbids it by law or regulation. In history, it has been also recognized that prostitution plays a functional role in the system of society. Purnomo and Siregar (1985) stated that many people actually owe to prostitutes. This is because when nautical sailors dropped in a certain location, they did not do only for business, but also because they wanted to look for sexual experience in that transit area. More fun experience they gained the more often the sailors would stop in that particular area and eventually develop a city with all kinds of equipment. Furthermore, when the city was already too crowded, commercial sex workers moved or transferred to the corners of the city away from the crowds, or localization. Even the corners of the city which was secluded and very quiet, they are still visited by men. So the longer the location was increasingly crowded and road infrastructure, transport and communications were built to facilitate the interaction of urban and rural communities where localization is placed. Shops and stalls were also easier to grow in the region and between the regions and other major connected cities. In this case, sexual behavior in prostitution is regarded as a social aberration, even though its presence will inevitably recognized to have great contribution to the growth of the city in a region. In essence, prostitution serves to save society, into a buffer, or at least enliven its existence as an entity among its members who requires an outlet for sexual desire outside of legal marriage. As individuals, commercial sex workers are victims of civilization which requires the sacrifice of the women sanctity.

Women prostitutes are mostly staying in cities, traffic areas for tourists and places of tourist destinations. In general, in these places there is a term, namely 4-S, which mean sea (the sea and the presence of water), sun (there is the sun), service, and sex. In Indonesia, legal prostitution practices are located in brothels or localizations, whereas the illegal one occurs in hotels, lodges and places of entertainment (Kartono, 2009).

What distinguishes between prostitution in developed and developing countries is that prostitutions in developing countries are located in transparent, "legal", and it can be visited at any time, and it can carry out transactions on the spot. While in developed countries, commercial sex workers will be arrested if the prostitutes offer themselves in any places because the profession is still considered as illegal and taboo, such as in the United States and some Western European countries. But in the Netherlands, prostitutes are allowed to operate legally for practicing a profession in accordance with the law specifically enacted by the government (Bachtiar and Purnomo, 2007).

\section{Methodology}

\subsection{Research Approach}

This study is a qualitative research with descriptive and analytical approaches that highlight the importance of examining and analyzing the life of a phenomenon or appearance of what is happening in a stream of consciousness. According to Byrne (2001), qualitative research examines life experiences (i.e., the lived experience) in an effort to understand and give them meaning. This is usually done by systematically collecting and analyzing narrative materials using methods that ensure credibility of both the data and the results.

Phenomenological approach is used in this study to keep away from the type of linear causal hypotheses and more emphasizes on cyclical process in which data collection and analysis takes place simultaneously. This approach is more concerned with the depth of research content rather than the breadth of research coverage, so that in-depth observation and interview techniques become very important in data collection, and researchers become the main instrument. Specifically, this study utilized phenomenologically oriented interviews (Byrne, 2001, Seidman, 2006;) with a non-random selection of respondents. With this phenomenological approach, researchers need to perform intensive interaction and communication with the subject under study, in which researchers should be able to understand and develop categories, patterns, and analysis of the social processes that occur in the middle of the subjects and the communities studied (Creswell, 1994). Therefore, this study examines the behavior of commercial sex workers where the phenomenology is applied to explore the meaning of commercial sex workers on their own behavior in the world of daily prostitution. The study uses grounded theory and has inductive characteristic which means the theory is built from data.

\subsection{Research Site}

This research was conducted in village Slorok, sub distric Kromengan, district Malang in East Java. Although the village 
is not productive, away from residential areas and located approximately 100 meters from main road of sub district Slorok, this location has been recognized by the residents of the surrounding communities as a place of prostitution. The location was named Kali Biru, so prostitution until now known as Localization of Kali Biru. In the localization, there are 14 guest houses 14, 15 pimps, 57 commercial sex workers, and 5 stalls.

The location of this research is very interesting because basically this place is away from the hustle of the city and located in isolated suburbs. With very minimal population density, most of the people in the area are migrants. Even so, this localization can still survive as a place of prostitution from the Dutch era until today. Another interesting phenomenon in this localization is though considered a semi-legal brothel which has not been allowed to be built in housing are, its existence has been known and tolerated by local authorities. Even the local government holds guidance to those who are involved in the prostitution business twice a month. The medical examination is also conducted regularly once a month. Counseling about HIV-AIDS problem is also commonly performed every 3 months.

\subsection{Data Collection Technique}

This study uses primary data which are obtained through observation in the study site with in-depth interview on the research subjects. In addition, this study also uses secondary data which are obtained by literature studies. In-depth interviews are conducted using in-depth interviews technique and structured interviews or using the interview guidelines which consist of a number of open questions which are intended to explore complete and in-depth information from informants.

\section{Results and Discussion}

Anomalous behavior including sexual intercourse with illegitimate partner may actually indicate that the person embraces a religion but do not practice it correctly. Many people who embrace a religion, but he did not want to live with the values of the religion in daily life. His presence at places of worship is only for his physical presence or to be seen by other people and not become public scorn (hypocritical behavior). Therefore, there is no fear of disobeying God's order.

Factors underlying the commercial sex workers may come from outside and within. From these factors, the most fundamental cause of a woman plunging into prostitution is their powerless to bear the heavy burden of life. Because of no power to bear the economic burden in the area of origin (village), they are easily tempted to accept an offer of any type employment to earn some money for living, no matter what kind of job. This is because their education is generally low and does not have good skills or expertise in another field. The presence of pressure due to household violence and family problems becomes part of the reasons for them to go into prostitution's world. In general, these factors are illustrated in the following table below:

Table 1: Driving Factors Their Characteristics of Commercial Sex workers

\begin{tabular}{|c|c|}
\hline Driving Factors & Detail \\
\hline Internal & $\begin{array}{l}- \\
\text { - }\end{array}$ \\
\hline External & $\begin{array}{l}\text { - lack of attention and efforts of the government and their surroundings to guide the commercial sex workers } \\
\text { towards a better life, } \\
\text { - lack of dialogue and openness between commercial sex workers with parents, families and spouse, } \\
\text { - } \text { family factors, such as parental divorce, left by her husband, } \\
\text { - } \text { socio-economic factors, such as social inequality, unemployment, and poverty, } \\
\text { - } \quad \text { environmental factor which is a place for the interaction between commercial sex workers with family, } \\
\text { friends, and her husband or partner. }\end{array}$ \\
\hline
\end{tabular}

On the other hand, the existence of commercial sex workers can be considered as a correction and introspection for all components in the society such as religious leaders, community leaders, and local government officials to revise the contribution and involvement in the mentoring and coaching of the commercial sex workers. There are a number of perspectives which can be used to explain the background of anomalous social behavior or aggression, such as: 1) 
biological reason, (2) results of the learning process, (3) a response to frustration, (4) as a result of social- cognitive factors such as economic pressure and social attacks, and (5) result from the interaction development of ecological factors. In addition, the ongoing and fast paced social changes resulted in inability of individual to adapt. It results in the emergence of disharmony, internal and external conflicts, and disorganization in society and individual. These situations facilitate people to use unconventional patterns of reaction or abnormal from common patterns. In this case, for a group of people, the profession as a commercial sex worker becomes an alternative for survival in the midst of the bustle nature of development.

Conditions of commercial sex workers in the village Slorok is in accordance with the perspective of Zaltman and Duncan (1977) who classified social changes based on their duration into six (6) types, namely:

1. Type 1: Social changes which occur in individuals in form of changes in attitude and behavior that take place in short term. For example, changing attitudes and behavior which can instantly change from bad to good. In coaching and mentoring by NGOs, commercial sex workers are given skills and guidance on entrepreneurship such as cooking, sewing, making various trinkets, beauty skills so as to provide the bustle and guidance to things that are positive. This activities aim to change the behavior of the commercial sex workers in order to socialize, communicate and have empathy to the community,

2. Type 2: the changes that take place in long term. This could be the provision of training to change the pattern of life of the commercial sex workers in accordance with particular environment. The localization in village Slorok, the commercial sex workers are given training about the importance of health. For example, they are given training on how to use condoms and how to maintain environmental cleanliness and personal hygiene to avoid the spread of venereal disease,

3. Type 3: The level of changes take place in short time such as changes in norms and how to work in accordance with her position as leader. This can be seen from the presence of a commercial sex worker who is selected by the pimps to be responsible for the condition of the occupants in the localization and its environment. He can steer his fellow sex workers to be empathetic and help her friends when in need of financial assistance. There exists tolerance which are instilled so that the localization conditions become conducive for everyone,

4. Type 4: Changes which occur in long term such as organizational changes, social changes which are needed to select leaders of an organization in order to support the existence and growth of the organization,

5. Type 5: Micro social changes that occur in short term where the changes are in accordance with the interests of education such as vocational or high school curriculum. These social changes are necessary to affect students or residents to learn. In this study, commercial sex workers have educational backgrounds which are relatively the same. Majority of them have low educational background or even have never attended to school. For commercial sex workers who have better education compared to others, they will have an impact on behavior and how she influenced her colleagues,

6. Type 6: Macro social changes which take place in long term, namely changes of culture among occupants with each other. Commercial sex workers come from varying family backgrounds. This condition can describe how they daily behave in their communities.

\section{Conclusion}

Factors underlying the social behavior of commercial sex workers are identified in this study. Commercial sex workers are a social construction resulting from macro social changes with driving factors on household violence, poor economics condition, debts, low income, skills, and low education. Commercial sex workers have way of life such as acting cool, stylish, glamor, lie to the family about her profession, adaptive to the environment, accustomed to living convenience, consumptive lifestyles, no debt, and always try to get money quickly in large amounts. Having very low knowledge about their religion background make them in dilemma where they have desire to run away from the profession but at the same time they are afraid of not getting enough money anymore to survive.

\section{References}

Bachtiar, R and E. Purnomo. (2007). Bisnis Prostitusi, Profesi yang Menguntungkan, Yogyakarta: Pinus Book Publisher.

Byrne, M. M. (2001). Understanding life experiences through a phenomenological approach to research. AORN Journal, 73(4), 830-832. Chang, H, Y. Weng. (2012). What is More Important for Prostitute Price? Physical Appearance or Risky Sex Behavior?" Economics Letters 117(2), 480-483. 
Creswell, J. W. (1994). Research Design: Qualitative and Quantitative Approaches, Thousand Oaks, CA: Sage Publications. Edlund, L. and E. Korn. (2002). A Theory of Prostitution, Journal of Political Economy, 110 (1), 181-214.

Jackson, L, Highcrest A, Coates RA. (1992). Varied Potential Risks of HIV Infection among Prostitutes. Soc Sci Med,35(3):281-286.

Kartono, K. (2009). Patologi Sosial, Jakarta: Rajawali Press.

Purnomo, T. and A. Siregar. (1985). Dolly: Membedah Dunia Pelacuran Surabaya, Kasus Kompleks Pelacuran Dolly, Jakarta: Graffiti Press.

Santo, M. E. G. D., and Etheredge, G. D. (2004). And then I became a prostitute... Some aspects of prostitution and brothel prostitutes in Dakar, Senegal. Social Science Journal, 41, 137-146.

Seidman, I. 2006. Interviewing as qualitative research: A guide for researchers in education and the social sciences, New York: Teachers College Press.

Soedjono D. (1977). Pelacuran Ditinjau dari segi Hukum dan Kenyataan dalam Masyarakat, Bandung :PT. Karya Nusantara.

Zaltman, G. and Duncan, R. (1977). Strategies for Planned Change, New York: John Wiley \& Sons. 